\title{
The Wearing of the Headscarf \& Labor Market Outcomes for Women in Turkey
}

Türkiye’deki Kadınlar için Başörtüsü Takmak ve İş Hayatına Katılım

Zeynep B. Uğur*

\begin{abstract}
Historically, female labor force participation (FLFP) rate has been very low in Turkey. As the majority of women in Turkey wear headscarves, this study examines if the ban on the religious garb contributed to the low FLFP rate. The study links the wearing of headscarves to labor market outcomes for women using the individual level data from 2 rounds of the National Demographic and Health Surveys (NDHS) conducted in 2003 and 2008, and 2 surveys conducted by the Konda Research Company in 2007 and 2011. After controlling other religious behaviors and values, it is demonstrated that urban women who wear headscarves are $3.6 \%$ to $8.5 \%$ less likely to be employed while the rate increases to between $17 \%$ to $28.2 \%$ among women with a university degree. This suggests that the impact of the headscarf ban was more damaging among women with degrees.
\end{abstract}

Keywords: Headscarf, Female Labor Force Participation, Turkey.

$\ddot{O} z \bullet$ Türkiye'de tarihsel olarak kadınların iş hayatına katılım oranları çok düşüktür. Bu çalışmada Türkiye'deki kadınların çoğunun başörtüsü

* Department of Economics AZ07, Hükümet Meydanı No:3, 06530 Ankara Social Sciences University of Ankara/ Turkey, zeynep.ugur@asbu.edu.tr, Orcid ID: 0000-0002-5141-2529

\footnotetext{
Başvuru: 20 Şubat 2018

Kabul: 1 Haziran 2018

Copyright (c) 2018 • KADEM Kadın ve Demokrasi Derneği kadinarastirmalari.kadem.org.tr

DOI: 10.21798/kadem.2018141982

ISSN 2149-6374 • Haziran 2018 • 4 (1) • 51 - 76
} 
kullanmasına rağmen uygulanan başörtüsü yasağının kadınların iş hayatına katılımının düşük olmasında rolü olup olmadığı incelenmiştir. Bu amaçla, 2003 ve 2008 yıllarında yapılan Türkiye Nüfus ve Sağlık Araştırması (TNSA)'nın bireysel düzeydeki verileri ve Konda Araştırma Şirketi tarafından 2007 ve 2011 yıllarında yapılan 2 anket kullanılarak kadınların başörtüsü takma durumu iş hayatı çıktıları ile ilişkilendirilmiştir. Diğer dini hayat ile ilgili davranışlar ve değerler kontrol edildikten sonra, kentte yaşayan kadınlar arasında başörtüsü kullananların çalışıyor olma ihtimali \%3.6 - \%8.5 oranında daha düşüktür. Bu oran üniversite mezunu başörtülü kadınlar için \%17 ila \%28.2'ye kadar daha düşüktür. Bu bulgular, başörtüsü yasağının özellikle üniversite eğitimi almış kadınları daha çok etkilediği sonucuna götürmektedir.

Anahtar Kelimeler: Başörtüsü, Kadının İşhayatına Katılımı, Türkiye.

\section{Introduction}

Historically, the female labor force participation (FLFP) rate has been very low in Turkey. For the 1990-2016 period, on average $30.7 \%$ of females participated in the labor market whereas the rate among men were $77.8 \%$ (See Figure A.1). Turkey's FLFP rate is the lowest among OECD countries, which has an average $60 \%$ FLFP rate for the same period. ${ }^{1}$ Although Turkey shares some of the characteristics of the Middle East and North Africa region, Turkey's FLFP rate, interestingly, has been lower than even some Islamic countries. Indeed, according to Global Gender Gap report (2007) by World Economic Forum, Turkey is ranked 108th among 115 countries in this regard, behind Bangladesh, Tunisia, Syria, Algeria and Qatar. Intervening years have not created any progress in terms of gender equality. As the 2016 edition of the Global Gender Gap report shows, Turkey ranks $130^{\text {th }}$ country among 144 countries, again behind Bangladesh, Tunisia, Algeria and Qatar. In the Global Gender Gap 2016's country analysis, lower FLFP was cited as a weakness preventing Turkey achieving gender equality.

There are various reasons for the low FLFP in Turkey. One reason is the migration from rural to urban areas starting in 1980s

1 The $2^{\text {nd }}$ lowest FLFP rate belongs to Mexico among OECD countries which has 42.6\% FLFP rate for 1990-2016 period. 
(Dayığlu \& Kırdar, 2010). Women who previously were unpaid family workers did not (could not) find jobs when they migrated to urban areas, as they lacked the necessary skill sets urban jobs. Başlevent and Onaran (2004) found a mild positive effect of exportoriented growth strategy on the FLFP. However, the main finding of Baslevent and Onaran (2004) is that female labor force responds more strongly to long term economic growth rather than temporary changes brought by business cycles. Tansel (2002)'s findings suggest a U-shaped relationship between FLFP rate and the level of economic development in Turkey, a conclusion that is also supported by the findings of Cagatay and Ozler (1995), who used date from 165 countries. Using cross-sectional data, Dayioglu (2000) found that the level of education, marital status and number of children are important determinants of labor market status.

There are many findings that show the importance of social norms on FLFP rates in other countries (Fernandez, Fogli, \& Olivetti, 2004). Indeed, social norms in Turkey are not conducive to female employment. ${ }^{2}$ Dedeoğlu (2010) discusses how women's roles as mothers and wives prevent them from engaging in paid work. İlkkaracan (2012) also finds similar evidence based on micro level data. She discusses the sociological reasons for the lower FLFP rate and argues that a gender-based division of labor and value judgments prevent women from market-based economic activity.

Lately, there has been arguments alleging conservatism as a social discourse is perpetuating the already low FLFP. Ilkkaracan (2012), together with Göksel (2013) and Atasoy (2016), argue that religiosity and culturally conservative attitudes are the reason behind lower FLFP. As Goksel (2013) rightfully acknowledges, both men and women in Turkey are very devout (See Table 1). However, one crucial aspect Turkey's social dynamics is ignored when conservatism is seen as the main impediment to increasing the FLFP rate in Turkey. Although the ruling elite of Turkey before 2000 passed several very progressive regulations to empower women, ${ }^{3}$ there remained a -............

2 Around $60 \%$ of participants' to World Values Survey 2001 in Turkey are of the opinion that when jobs are scarce, men should be given priority over women.

3 Turkey became a member of the United Nations' Committee on the Elimination 
gap between the religiosity of citizens and the ruling elite's desire to modernize and secularize. ${ }^{4}$ This gap itself produced a very strict headscarf ban, even though the majority of women in Turkey wears a headscarf.

Carkoglu and Toprak (2006) reports that 63.5\% of women in Turkey wear some sort of headscarf. Konda 2007 survey found that $69.6 \%$ of women in Turkey wear headscarves (GYDLTA, 2007). Similarly, the A\&G's surveys found that the percentage of households in which women did not wear headscarves was 21.5 and 16.6 in 2003 and 2007, respectively (TA, 2003-2007). Also, Carkoglu \& Toprak (2006) reports that $25 \%$ of the respondents said they would disapprove if their daughters took off their headscarves just to continue their education. Konda 2007 also reports that $26 \%$ of the respondents would prefer their daughters to forgo their university education rather than uncover their heads. As many people are of the opinion that the headscarf cannot be discarded in order to attain legitimate objectives, such as education, one can deduce that, many women and men would consider wearing of the headscarf as an essential element for women's labor market participation.

Yet, in 1997, a very strict ban was imposed against wearing of the headscarf, which remained active in practice until 2009. The ban was officially lifted only in 2013. The ban on the religious symbol ${ }^{5}$ covered all public spaces, including universities and other public institutions, as it was thought it should have no place in the public life of a secular Turkey. ${ }^{6}$ However, the majority of the public

of Discrimination against Women (CEDAW) in 1985 (Directorate General on the Status of Women, 2011). A Turkish directorate general was established under the Prime Ministry in 1990 for improving the status of women in society. Moreover, a new labor law was enacted in 2003 to strengthen the legal measures against gender discrimination in the labor market (Directorate General on the Status of Women, 2008).

4 How such a gap can happen in democratically ruled country like Turkey is an interesting question, but this is beyond the scope of this paper.

5 According to some, headscarf was not only a religious symbol but also a political symbol (See Hürriyet, 2003).

6 The ban was enacted as a result of a National Security Council meeting later named as ' $28^{\text {th }}$ February Postmodern coup'. For detailed information on the historical events related to the headscarf ban, one can consult Ugur (2017). 
actually opposed the headscarf ban. According to Konda (2007) survey, $78 \%$ of the respondents said they are against the headscarf ban in universities.

As a result of this ban, women at universities were forced to drop out, while civil servants quit their jobs if they continued to wear the headscarf. According to AK-DER (2010), 5,000 women who wore a headscarf were sacked between 1998 and 2002 and another10,000 were forced to quit, because going to work wearing a headscarf was considered insubordination. From 2000 onwards, women who applied to become civil servants were forced to enter entrance tests "with uncovered heads." Moreover, apart from the ban's impact on women's labor market prospects by restricting educational opportunities and preventing employment in the public sector, there were also limitations imposed on private sector opportunities. In professions requiring practitioners to be registered to professional organizations, such as doctors, pharmacists, dentists, lawyers, and notaries, the professional Chambers and Unions issued circulars outlawing the headscarf. Cindoglu (2010) also argues that the ban had a spill-over effect in the private sector. According to Cindoglu (2010)'s interviews with headscarved women, private companies did not prefer to hire them because they could not do anything that included visiting a public office. Those women had to be invisible in offices. Due to the inherent nature of white-collar jobs, a journalist, an engineer, or a banker would have to deal with many different institutions, some of which may have the ban on the headscarf in place. Encounters with such institutions could result in poor performances, which could in turn make the woman with the headscarf a liability for the company. Cindoglu (2010) suggests that even if there were no discriminatory motivations or intentions by the company, the existence of the headscarf ban created a hostile environment for professional women who want to wear it.

In this study, we examine how the wearing of headscarf is related to labor market outcomes for women. Cindoglu (2010) studied the headscarf ban through in-depth interviews with 79 women. But, the group was not representative and the number of observations was few due to the nature of that study. 
The ban did harm the labor market prospects of women who wore the headscarf. However, the effect depended on how attached a woman was to her job before the imposition of the ban and her bond with the headscarf. Carvalho (2013) suggests women who continue to wear the headscarf despite everything the society throws at them display a cultural resistance based on devoutness. Ugur (2017) shows that $72 \%$ of headscarved women in Konda 2007 dataset reported that they wore the scarf due to their own religious devotion. ${ }^{7}$ Ugur (2017) also shows that the ban did not cause a sudden drop in the portion of women wearing the headscarf.

There are studies casting doubt on religious women's willingness to work. Clark, Ramsbey, and Adler (1991) finds lower FLFP in Muslim and Latin American countries. Assad (2005) blames conservatism prevalent in the Egyptian society for the low FLFP rate. However, there is also a supply side effect in which employers expect candidates for the top positions not to wear the headscarf as it is associated with backwardness (Carvalho, 2013). On the other hand, headscarved women argue that the religious garb affords them advantages like safety and authenticity while entering public spaces, which is traditionally thought to be the men's domain (Read \& Bartkowski, 2000).

Individual level data from four surveys are used to study the impact of the headscarf ban. Ideally, the data would reflect the headscarf use and labor market conditions before and after the ban. However, we only have individual level data for headscarf use after the ban. Therefore, no evidence can be provided on how the ban affected the use of the headscarf. However, there is evidence on how wearing the headscarf is linked to the labor market outcomes controlling for a large set of other religious behaviors.

To the researcher's knowledge, this study is the first of its kind that demonstrates the effect of the headscarf ban on female labor market outcomes on a representative scale. This issue is clearly important, as in many countries the headscarves of Muslim women is

$77 \%$ wear it due to their family member's request, $16 \%$ wear it due to customs/ traditions, $4.66 \%$ wear it to be in accord with their environment (Ugur, 2017). 
an issue of considerable importance and in recent years many politicians have publicly supported the banning of the headscarf. (See Chick (2010); Dunbar (2009); Human Rights Watch (2009); Mardell (2006); Saharso (2007); Vakulenko (2007))

\section{Background of the Headscarf Ban in Turkey}

The headscarf ban was first enforced in all public institutions (all universities and public buildings) across Turkey in the 1960s. In this paper, we focus on regulations involving the labor market. When the Republic was first founded in 1923, nothing limiting women's garbs was introduced. (Jenkins, 2008). Yet, implicitly, until recently, the secularist elite running the country was uneasy about the headscarf (Hoodfar, 1991). Until the 1970s, there were no women with headscarves working at public institutions. And afterwards, except certain rare cases, ${ }^{8}$ there were only a small number of professional women, such as among teachers and professors at universities, wearing headscarves at public institutions. In the 1980s, when the headscarf became more visible with the increase in the number of women working at public institutions and going to university, the ruling elite of the country felt more uncomfortable.

At the time, there were no laws explicitly preventing women from wearing the headscarf. The ban would be enforced through regulations. The first set of regulations about the proper dress code for women working at public institutions that contains articles on women's head/hair was enacted in 1982 (The Official Gazette, 1982). This allowed some institutions to strictly prohibit the use of the headscarf, while others simply ignored the rules. Different institutions had differing attitudes toward the limitation. However, for academic research, the period lacks any workable data, because what the local executive thought about it usually decided the matter. Anecdotal evidence suggests that it was loosely applied in rural areas, whereas in big cities like Ankara and Istanbul, civil servants were under tighter scrutiny in order to prevent the wearing of the headscarf.

8 Lawyer Emine Aykenar was expelled from the Chamber of Lawyers which essentially mentions that she can not work as a lawyer on the grounds of her headscarf by the then president Yekta Güngör Özden (Aksoy, 2005). 
The National Security Council meeting on 28 February 1997 introduced an entirely new reality for women wearing the headscarf. In that longer than usual meeting, several decisions were taken to prevent any breach of the principle of secularism ${ }^{9}$ in the Constitution (National Security Council, 1997). Although the headscarf was not explicitly mentioned in any of the decisions, the 13th resolution of the council mentioned the so-called modern way of dressing. The headscarf was interpreted as being opposed to secularism and the modern way of dressing and its use was strictly prohibited at universities and other public institutions. It was the narrowest and the harshest interpretation of the nationwide ban. The ban was still enforced as late as 2008. That year, an initiative took place to lift the ban. The Constitutional Court decided to preserve the ban on the grounds that headscarves violated the principle of secularism in the Constitution (The Official Gazette, 2008).

The Union of Turkish Bar Associations (1971) regulations say lawyers can only enter the courtroom without the headscarf. Although some doctors were able to work with the headscarf before $1997,{ }^{10}$ Benli (2011) reports several cases, especially at the Istanbul University's Cerrahpaşa Hospital, where doctors were prevented from doing their jobs because of their headscarf.

\section{Methodology}

The regression analysis used explains women's employment status as a function of control variables and the use of headscarves. As female labor market outcomes are found to be less favorable in Muslim countries, we control for the individual's own reported degree of devoutness, the frequency of daily prayers, fasting and the reading of Quran to account for the potentially lower demand for employment among religious people. Attitudes towards women's contribution to the family budget are also included. The place of birth and the current address of residency are used to analyze the possible effects

9 Securalism in Turkey is more of French type laicite rather than Anglo-Saxon secularism (Kuru, 2009).

10 Hümeyra Öktem was reported to work in Tuberculosis dispensary in 1955 and thereafter other public hospitals (Benli, 2011). 
of upbringing and social norms in different regions. The analysis includes the largest possible control variables to isolate the impact of the headscarf ban from the supply side conservative attitudes and other factors that might reduce a person's prospects of employment. To identify the effect of the ban, the study assumes women who wear and do not wear the headscarf are similar in all other ways. Women who were younger than 17 at the time the ban was imposed were ignored, as they are considered child labor. Women from rural areas were likewise ignored as their employment is usually involves unpaid agricultural work on family plot and does not conform to the normal labor supply analysis.

\section{Data}

We use 2 rounds of the National Demographic and Health Survey (NDHS) conducted in 2003 and 2008 obtained from the Ankara Hacettepe University Institute of Population Studies and 2 surveys conducted in 2007 and 2011 by the Konda Research Company for this study (NDHS, 2003-2008; GYDLTA, 2007; BK, 2011).

\subsection{NDHS Datasets}

The NDHS are conducted by the Hacettepe University's Institute of Population Studies every 5 years. It is based on a representative sample of married women between the ages of 15 and 49. In the 2003 and 2008 surveys, women were asked whether they wore the headscarf or not. ${ }^{11}$ Those who regularly wear the headscarf when going out are categorized as headscarved in our study. The 2003 survey was conducted among 8,075 women; the 2008 survey was conducted among 7,405 women. The women came from all across the country. With the sample restrictions (no younger than 17 years old at the time of survey, urban), the sample shrinks to 11,363 women $(5,962$ and 5,420 in 2003, 2008, respectively). The descriptive statistics are shown in Table $1.70 \%$ of the sample reportedly wore headscarves.

11 The wording of the headscarf question in NDHS-2003 is the as follows: "Do you wear a head scarf when you go outside the street?" The answers are categorized as; Yes and No in 2003. In 2008, for the same question, the answers are categorized as; 'Yes, regularly', 'yes, irregularly' and 'No'. 
Women with and without the headscarf differed in significant ways. Headscarved women were less likely to be employed, especially in the public sector as expected. Only $18 \%$ of the headscarved women are employed, $8 \%$ of those employed are in the public sector and $92 \%$ are in the private sector. However, $34 \%$ of women without the headscarf are employed. Among the employed women who do not wear the headscarf, 34\% are employed in the public sector and $66 \%$ are employed in the private sector. There is also a big education gap between women with and without the headscarf. Only $3 \%$ of women with the headscarf have bachelor degrees, whereas $21 \%$ of women without the headscarf have a university diploma. Moreover, the parents of headscarved women are more likely to be less educated, speak Kurdish as their mother tongue, have reiceved a religious education, live in Central or Eastern Anatolia, pray and fast more often. Women who do not wear a headscarf are more likely to be wealthier, have more educated parents, speak Turkish as their mother tongue, wear make-up and live in Western and Southern parts of Turkey.

\begin{tabular}{lccc}
\hline & Entire Sample & Headscarved & $\begin{array}{c}\text { Non- } \\
\text { Headscarved }\end{array}$ \\
\hline Wears headscarf & $0.70[0.46]$ & & \\
Employed & $0.23[0.42]$ & $0.18[0.38]$ & $0.34[0.47]^{* * *}$ \\
Works in Public sector & $0.20[0.40]$ & $0.08[0.28]$ & $0.34[0.48]^{*+*}$ \\
Works in Private Sector & $0.80[0.40]$ & $0.92[0.28]$ & $0.66[0.48]^{* * *}$ \\
Education Level & $2.29[1.40]$ & $1.87[1.23]$ & $3.29[1.27]^{* * *}$ \\
Less than primary school & $0.20[0.40]$ & $0.26[0.44]$ & $0.04[0.20]^{* * *}$ \\
Between primary to high & $0.72[0.45]$ & $0.71[0.45]$ & $0.75[0.44]^{* * *}$ \\
school & $0.08[0.27]$ & $0.03[0.16]$ & $0.21[0.41]^{* * *}$ \\
Some university or higher & $34.00[8.28]$ & $34.09[8.39]$ & $33.78[8.02]$ \\
Age & $3.39[1.28]$ & $3.12[1.25]$ & $4.04[1.12]^{* * *}$ \\
Wealth index score & $0.75[1.05]$ & $0.52[0.86]$ & $1.29[1.25]^{* * *}$ \\
Mother's education level & $1.61[1.28]$ & $1.37[1.19]$ & $2.16[1.32]^{* * *}$ \\
Father's education level & $0.81[0.39]$ & $0.77[0.42]$ & $0.93[0.26]^{* * *}$ \\
Mother tongue: Turkish & & &
\end{tabular}




\begin{tabular}{|c|c|c|c|}
\hline Mother tongue: Kurdish & $0.16[0.36]$ & $0.21[0.41]$ & $0.04[0.19]^{*+*}$ \\
\hline Mother tongue: Other & $0.03[0.16]$ & $0.02[0.16]$ & $0.03[0.18]^{\star}$ \\
\hline Residence Region: West & $0.31[0.46]$ & $0.26[0.44]$ & $0.43[0.50]^{*+*}$ \\
\hline Residence Region: South & $0.13[0.34]$ & $0.12[0.33]$ & $0.17[0.37]^{*+*}$ \\
\hline Residence Region: Central & $0.19[0.39]$ & $0.20[0.40]$ & $0.16[0.37]^{*+*+}$ \\
\hline Residence Region: North & $0.11[0.32]$ & $0.11[0.31]$ & $0.11[0.32]$ \\
\hline Residence Region: East & $0.26[0.44]$ & $0.31[0.46]$ & $0.13[0.33]^{*+*}$ \\
\hline \# of living children & $2.35[1.64]$ & $2.65[1.75]$ & $1.64[1.05]^{+* t+}$ \\
\hline Wears make-upa & $0.44[0.50]$ & $0.28[0.45]$ & $0.80[0.40]^{+*+x}$ \\
\hline Had religious education ${ }^{\mathrm{a}}$ & $0.41[0.49]$ & $0.45[0.50]$ & $0.31[0.46]^{*+\alpha}$ \\
\hline Prays compulsory prayers ${ }^{b}$ & $1.29[0.79]$ & $1.53[0.68]$ & $0.69[0.73]^{*+\alpha}$ \\
\hline Fasts $^{b}$ & $1.82[0.52]$ & $1.95[0.28]$ & $1.50[0.79]^{*+\alpha+}$ \\
\hline$N$ & 11,363 & 7,993 & 3,370 \\
\hline
\end{tabular}

Table 1. Descriptive Statistics (NDHS Sample)

Notes: Table shows the mean coefficients and standard deviations in brackets, ${ }^{*} p<0.05,{ }^{* *} p<0.01,{ }^{* * * *} p<0.001$

a: asked only in 2003, b: only in 2008. The other questions are administered in both waves.

\subsection{Konda Datasets}

The study also uses the two surveys conducted by the Konda Research Company. The first survey was conducted in 2007 with 5,291 respondents; the second one was conducted in 2011 with 6,481 respondents. The Konda Research Company specializes in providing information on socio-economic issues. These surveys collect a wide range of data related to religious practices and social values of women. The data was collected through face to face interviews across Turkey. Respondents are eighteen and older, and the sample is representative of Turkey's non-institutionalized adult population. For the purpose of this study, the two datasets were pooled together. Men, female students and rural women were discarded, with the remaining 4,642 women the basis of the study. All women who say 
that they wear headscarves are categorized as headscarved. ${ }^{12} 63.62 \%$ of women said they wore a headscarf in the 2007 survey, whereas the percentage was $69.35 \%$ in 2011 .

Table 2 provides descriptive information from the Konda surveys on the use of the headscarf. There are sharp and statistically significant differences in all job types and overall employment status between women wearing headscarves and those who don't. Only $11 \%$ of women who wore headscarves are employed while the rate is $34 \%$ among those who didn't. A look into the categories of employment shows that women wearing headscarves are less likely to be employed in the public sector and the private sector, and are also less likely to be self-employed. The gap in the public sector is no surprise. However, the sharp difference in the private sector is in line with the arguments of Cindoglu (2010). The data shows that headscarved women are more likely to be less educated, live in larger households, be older, married, less well to do, born and living in the Black Sea region, Northeast, Southeast, or Central Anatolia. Moreover, headscarved women describe themselves as being more devout and follow other religious indicators (daily prayers, fasting, regular reading of the Quran, voluntary prayer) more frequently compared to women without the headscarves. Women wearing a headscarf are less supportive of women contributing to the family budget. A question in the Konda survey in 2007 asked the respondents to choose the two most important aspects of their lives. Possible answers are respect/reputation in social life, being connected to customs and traditions, material affluence, having a modern family life, career/ success in work. Based on their answers to this question, the value structure of headscarved and non-headscarved are very different. Headscarved women are more likely to value being attached to customs and traditions, whereas women who do not wear a headscarf are more likely to value respect and reputation in society, material affluence, having a modern family life and career. In the Konda 2011 survey, respondents are asked about their ideas on whether

12 The wording of the headscarf question is as follows: "Is there anyone at this household who covers her head when she goes out for shopping, city center, walking etc. If so, who? The answer categories are the following: Yes, I do; Yes, my daughter; Yes, my mother; Yes, my grandmother; Yes, others; Nobody. 
new technologies are beneficial for them. Headscarved women are more likely to be skeptical about new technologies. There is a wide gap between employment status of women with tertiary education depending on their use of the headscarf. According to the Konda surveys, among women with a tertiary education, $47.2 \%$ of those wearing a headscarf are employed, while $69.4 \%$ of women without the scarf are employed.

\begin{tabular}{|c|c|c|c|}
\hline & Entire Sample & Headscarved & $\begin{array}{r}\text { Non- } \\
\text { Headscarved }\end{array}$ \\
\hline Wears headscarf & $0.67[0.47]$ & & \\
\hline Employed & $0.18[0.39]$ & $0.11[0.31]$ & $0.34[0.47]^{* * *}$ \\
\hline Public Sector employee & $0.03[0.16]$ & $0.01[0.08]$ & $0.07[0.25]^{* * *}$ \\
\hline Private Sector employee & $0.08[0.27]$ & $0.04[0.20]$ & $0.16[0.36]^{* * *}$ \\
\hline Self-employed & $0.08[0.26]$ & $0.06[0.23]$ & $0.11[0.31]^{* * *}$ \\
\hline House-maker & $0.71[0.45]$ & $0.82[0.39]$ & $0.49[0.50]^{* * *}$ \\
\hline Retired & $0.04[0.21]$ & $0.03[0.17]$ & $0.07[0.26]^{* * *}$ \\
\hline Unemployed & $0.03[0.18]$ & $0.02[0.12]$ & $0.07[0.25]^{* * *}$ \\
\hline Unable to work & $0.03[0.17]$ & $0.03[0.16]$ & $0.03[0.17]$ \\
\hline Educ:Primary School or less & $0.62[0.49]$ & $0.77[0.42]$ & $0.30[0.46]^{* *+}$ \\
\hline $\begin{array}{l}\text { Educ:Secondary/ High School } \\
\text { graduate }\end{array}$ & $0.31[0.46]$ & $0.21[0.41]$ & $0.51[0.50]^{*+*}$ \\
\hline Educ:University or more education & $0.07[0.26]$ & $0.01[0.11]$ & $0.19[0.40]^{* * *}$ \\
\hline$\%$ younger than 28 years old & $0.28[0.45]$ & $0.22[0.42]$ & $0.39[0.49]^{\star * *}$ \\
\hline$\%$ household size less than 5 people & $0.80[0.40]$ & $0.75[0.43]$ & $0.92[0.28]^{\star \star *}$ \\
\hline \% family income less than $1200 \mathrm{TL}$ & $0.79[0.41]$ & $0.87[0.34]$ & $0.63[0.48]^{* *+}$ \\
\hline Single/Engaged & $0.14[0.35]$ & $0.07[0.26]$ & $0.27[0.45]^{* *}$ \\
\hline Married & $0.78[0.41]$ & $0.84[0.36]$ & $0.66[0.47]^{* * *}$ \\
\hline Widowed/Divorced & $0.08[0.27]$ & $0.09[0.28]$ & $0.07[0.25]^{* * *}$ \\
\hline Region of Residence: Istanbul & $0.19[0.40]$ & $0.16[0.37]$ & $0.26[0.44]^{* * *}$ \\
\hline Region of Residence:West Marmara & $0.05[0.21]$ & $0.04[0.20]$ & $0.05[0.22]$ \\
\hline Region of Residence:Aegean Region & $0.14[0.35]$ & $0.11[0.31]$ & $0.20[0.40]^{* * *}$ \\
\hline Region of Residence:Eastern Marmara & $0.09[0.29]$ & $0.10[0.30]$ & $0.07[0.25]^{* * *}$ \\
\hline
\end{tabular}




\begin{tabular}{|c|c|c|c|}
\hline Region of Residence:Western Anatolia & $0.12[0.32]$ & $0.12[0.33]$ & $0.12[0.32]$ \\
\hline Region of Residence: Mediterranean & $0.13[0.33]$ & $0.12[0.33]$ & $0.13[0.34]$ \\
\hline Region of Residence:Central Anatolia & $0.05[0.22]$ & $0.06[0.24]$ & $0.03[0.17]^{* * *}$ \\
\hline $\begin{array}{l}\text { Region of Residence: Western Black } \\
\text { Sea }\end{array}$ & $0.06[0.24]$ & $0.07[0.26]$ & $0.03[0.18]^{* *+}$ \\
\hline Region of Residence: Eastern Black Sea & $0.03[0.18]$ & $0.04[0.19]$ & $0.02[0.14]^{* *}$ \\
\hline $\begin{array}{l}\text { Region of Residence:North-East } \\
\text { Anatolia }\end{array}$ & $0.02[0.13]$ & $0.02[0.15]$ & $0.01[0.08]^{*+*}$ \\
\hline Region of Residence: East Anatolia & $0.03[0.18]$ & $0.04[0.18]$ & $0.03[0.16]$ \\
\hline $\begin{array}{l}\text { Region of Residence: South East } \\
\text { Anatolia }\end{array}$ & $0.07[0.26]$ & $0.09[0.29]$ & $0.03[0.18]^{* *+}$ \\
\hline Region of Birth: Istanbul & $0.07[0.26]$ & $0.04[0.19]$ & $0.14[0.34]^{* * *}$ \\
\hline Region of Birth: West Marmara & $0.05[0.22]$ & $0.04[0.21]$ & $0.06[0.24]^{*}$ \\
\hline Region of Birth: Aegean Region & $0.12[0.32]$ & $0.09[0.29]$ & $0.17[0.37]^{*+*}$ \\
\hline Region of Birth: Eastern Marmara & $0.07[0.26]$ & $0.08[0.27]$ & $0.06[0.24]^{* *}$ \\
\hline Region of Birth: Western Anatolia & $0.10[0.30]$ & $0.10[0.30]$ & $0.08[0.28]^{\star}$ \\
\hline Region of Birth: Mediterranean & $0.13[0.34]$ & $0.12[0.33]$ & $0.14[0.35]$ \\
\hline Region of Birth: Central Anatolia & $0.08[0.27]$ & $0.09[0.29]$ & $0.06[0.23]^{*+*}$ \\
\hline Region of Birth: Western Black Sea & $0.10[0.30]$ & $0.11[0.31]$ & $0.09[0.28]^{* *}$ \\
\hline Region of Birth: Eastern Black Sea & $0.07[0.26]$ & $0.08[0.27]$ & $0.06[0.23]^{*}$ \\
\hline $\begin{array}{l}\text { Region of Birth: North-Eastern } \\
\text { Anatolia }\end{array}$ & $0.05[0.22]$ & $0.06[0.23]$ & $0.04[0.19]^{* *}$ \\
\hline Region of Birth: Eastern Anatolia & $0.05[0.22]$ & $0.05[0.22]$ & $0.05[0.21]$ \\
\hline Region of Birth: South East Anatolia & $0.09[0.29]$ & $0.12[0.32]$ & $0.05[0.21]^{* *+}$ \\
\hline Region of Birth: Abroad & $0.01[0.12]$ & $0.01[0.10]$ & $0.02[0.15]^{* * *}$ \\
\hline Self-Reported Religiosity & $3.79[0.68]$ & $4.00[0.58]$ & $3.37[0.67]^{*+*}$ \\
\hline Fasting & $2.66[0.59]$ & $2.80[0.45]$ & $2.36[0.73]^{*+\alpha}$ \\
\hline Daily compulsory prayers & $2.25[0.71]$ & $2.49[0.60]$ & $1.77[0.65]^{* *+}$ \\
\hline Reading the Quran ${ }^{a}$ & $2.02[0.83]$ & $2.19[0.83]$ & $1.71[0.74]^{*+*}$ \\
\hline Voluntary Prayer ${ }^{\mathrm{a}}$ & $2.78[0.46]$ & $2.88[0.32]$ & $2.59[0.60]^{*+*}$ \\
\hline Women should work ${ }^{\mathrm{a}}$ & $0.73[0.45]$ & $0.64[0.48]$ & $0.88[0.33]^{*+\alpha}$ \\
\hline Respect/Reputation ${ }^{a}$ & $0.47[0.50]$ & $0.43[0.50]$ & $0.54[0.50]^{* *+}$ \\
\hline Attached to Customs/Traditions ${ }^{a}$ & $0.56[0.50]$ & $0.61[0.49]$ & $0.48[0.50]^{*+\alpha}$ \\
\hline
\end{tabular}




\begin{tabular}{lrrr} 
Material Affluence $^{\mathrm{a}}$ & $0.05[0.22]$ & $0.04[0.19]$ & $0.07[0.26]^{+*+}$ \\
Having a Modern Family $^{\mathrm{a}}$ & $0.18[0.38]$ & $0.07[0.25]$ & $0.37[0.48]^{+*+}$ \\
Career/Success in Work $^{\mathrm{a}}$ & $0.18[0.38]$ & $0.13[0.33]$ & $0.27[0.44]^{+*+}$ \\
New technologies are beneficial $^{\mathrm{b}}$ & $3.73[0.83]$ & $3.67[0.85]$ & $3.87[0.78]^{+*+}$ \\
\hline$N$ & 4,565 & 3,066 & 1,499 \\
\hline
\end{tabular}

Table 2. Descriptive Statistics (Konda Sample)

Notes: mean coefficients; sd in brackets, ${ }^{*} \mathrm{p}<0.05,{ }^{* *} \mathrm{p}<0.01,{ }^{* * *} \mathrm{p}<0.001$, a: only in 2007 ;b: only in 2011

When we compare the NDHS and the Konda datasets, the former records a higher percentage of women with headscarves, mainly because the NDHS was conducted solely among married women while the Konda survey was conducted among all.

\section{Results}

The regression results in Table 3 show the relationship between the headscarf and labor market outcomes using all 4 datasets. In all datasets, the largest possible set of control variables, such as the respondent's level of education, age, place of birth and current place of residence, number of children etc, are used. It can be argued argued that there might be less demand for employment among religious women. To control for that, the respondent's desire for make-up when going out and whether she underwent a religious education are added to model (1). In model (2), respondents' frequency of performing the 5 daily prayers and fasting are added to the control variables. In model (3), respondent's own reported degree of devoutness, individual frequency of praying, fasting, reading of the Quran and the frequency of voluntary prayer are added as additional controls. To address the value structure differential, the attitudes towards women's contribution to the family budget, the respondent's regard for a career, material affluence and a modern family life are included in model 3. In model 4, the respondent's own description of her devoutness, frequency of prayer, fasting and attitude toward new technologies are added as extra control variables. Full regression results are available in Appendix Table A-1 and A-2. 


\begin{tabular}{|c|c|c|c|c|}
\hline & $\begin{array}{c}\text { NDHS-2003 } \\
(1)\end{array}$ & $\begin{array}{c}\text { NDHS-2008 } \\
(2)\end{array}$ & $\begin{array}{c}\text { Konda-2007 } \\
\text { (3) }\end{array}$ & $\begin{array}{c}\text { Konda-2011 } \\
\text { (4) }\end{array}$ \\
\hline \multirow[t]{2}{*}{ Headscarf } & $-0.085^{\star \star *}$ & $-0.047^{* * *}$ & $-0.061^{\star * \star}$ & $-0.036^{\star *}$ \\
\hline & $(0.01)$ & $(0.02)$ & $(0.02)$ & $(0.02)$ \\
\hline \multirow[t]{2}{*}{ Education Level } & $0.052^{* * *}$ & $0.044^{* * *}$ & $0.063^{* * *}$ & $0.057^{\star * \star}$ \\
\hline & $(0.01)$ & $(0.01)$ & $(0.01)$ & $(0.01)$ \\
\hline Baseline Controls & $++^{a}$ & $+^{a}$ & $++^{b}$ & $++^{\mathrm{b}}$ \\
\hline $\begin{array}{l}\text { Other Religious } \\
\text { Behaviors }\end{array}$ & $+^{c}$ & $+^{d}$ & $+^{e}$ & $+^{f}$ \\
\hline Values about Life & - & - & +9 & $+^{\mathrm{h}}$ \\
\hline $\mathrm{N}$ & 5,472 & 5,084 & 1,574 & 2,680 \\
\hline Pseudo R-sqr & 0.066 & 0.089 & 0.171 & 0.167 \\
\hline
\end{tabular}

Table 3. Probit Estimates of Employment Status (Marginal Effects)

a : the respondent's age, mother's and father's education level, region in which the respondent was living (5 categories), mother tongue, wealth index and number of children; 'b: age (3 categories), marital status, household size, household income, current region of residence (12 dummy variables), and region of birth (13 dummy variables). ${ }^{c}$ : make-up and had religious education; ${ }^{d}$ :frequency of praying and fasting; e:self-reported religiosity, praying, fasting, reading the Quran, voluntary prayer; ${ }^{\text {f. }}$ self-reported religiosity, praying, fasting; ${ }^{\text {: }}$ values material wealth, modern family life and career; ${ }^{\text {h: }}$ attitudes toward new technologies

From model (1), it was found that women who wore a headscarf are $8.5 \%$ less likely to be employed. The model (2) and (3) also show that women wearing a headscarf are $4.7 \%$ and $6.1 \%$ less likely to be employed, respectively. Model (4) also suggests that women with a headscarf are $3.6 \%$ less likely to be employed after accounting for an extensive set of controls.

As Dayığlu and Kırdar (2010) and İlkkaracan (2012) demonstrated before, a university education is the single most important determinant of labor force participation. In Table 4, the sample is restricted to university educated women to see the impact on this specific group. The result is that the headscarf reduces the probability of being employed from $28.2 \%$ to $17 \%$, which shows a deeper problem for highly educated women than those with fewer qualifications. However, the result makes sense in that occupations that 
necessitate a bachelor's degree usually require the employee to be more visible, which cannot easily go hand in hand with the headscarf ban. The Konda 2007 survey failed to provide a statistically significant result, probably due to the small sample size. There were only 113 women with bachelor degrees, only 15 of whom were headscarved.

\begin{tabular}{lcccc}
\hline & NDHS-2003 & NDHS-2008 & Konda-2007 & Konda-2011 \\
& $(1)$ & $(2)$ & $(3)$ & $(4)$ \\
\hline Headscarf & $-0.187^{* \star \star}$ & $-0.170^{\star \star \star}$ & -0.152 & $-0.282^{\star \star}$ \\
& $(0.06)$ & $(0.06)$ & $(0.15)$ & $(0.12)$ \\
\hline Baseline Controls & $+^{\mathrm{a}}$ & $+^{\mathrm{a}}$ & $+^{\mathrm{b}}$ & $+^{\mathrm{b}}$ \\
\hline Other Religious & $+^{\mathrm{c}}$ & $+^{\mathrm{d}}$ & $+^{\mathrm{e}}$ & $+^{\mathrm{f}}$ \\
Behaviors & - & - & $+^{\mathrm{g}}$ & $+^{\mathrm{h}}$ \\
\hline Values about Life & 466 & 450 & 113 & 176 \\
\hline $\mathrm{N}$ & 0.043 & 0.082 & 0.315 & 0.204 \\
\hline Pseudo R-sqr & & & & \\
\hline
\end{tabular}

Table 4. Probit Estimates of Employment Status (Marginal Effects)

a : the respondent's age, mother's and father's education level, region in which the respondent was living (5 categories), mother tongue, wealth index and number of children; b: age (3 categories), marital status, household size, household income, current region of residence (12 dummy variables), and region of birth (13 dummy variables)..$^{\text {: }}$ make-up and had religious education; ${ }^{d}$ :frequency of praying and fasting; e:self-reported religiosity, praying, fasting, reading the Quran, voluntary prayer; ${ }^{\text {f: }}$ self-reported religiosity, praying, fasting; ${ }^{\text {g: }}$ values material wealth, modern family life and career; ${ }^{\text {h: }}$ attitudes toward new technologies. Full regression results are available upon request.

Having said that, women who wear the headscarf were aware that they might be narrowing their employment prospects. Therefore, we cannot ignore the possibility that women who do not want to work were more likely to wear a headscarf. Yet, according to the results of this study, women who wear headscarves still have significantly lower employment prospects even after controlling for a wide range of religious practices and social values. Thus, this study infers that due to the ban, the labor market conditions were not favorable to the employment of women wearing headscarves. 


\section{Discussion}

The descriptive statistics in Table 2 shows that only $2 \%$ of women with headscarves were unemployed whereas $7 \%$ of the nonheadscarved women were unemployed. It can be argued that the ban disenfranchised the women with headscarves and consequently made it harder for them to find jobs, making us expect a higher percentage of unemployed. However, the data can also indicate that most of these women were not seeking work in the first place. In economics literature, there are many studies (See Kottis (1990); Tansel (2001)) showing the importance of so-called "discouraged worker effect," especially among women. According to the discouraged worker effect, the status unemployed may hide the real portion of unemployed women, as many women refrain from entering the job search process under the expectation that the time and energy spent in searching for a job will not be compensated by the salary earned, which is in anyway unequal. Most of those who are not looking for work, and consequently are not included among the unemployed, would join the labor force if the labor market conditions are favorable. Karaoglan and Okten (2012) finds a substantial discouraged worker effect among women between 2000-2010. Therefore, the lower proportion of the unemployed among headscarved women can be explained through this effect.

Secondly, it is worth clarifying that this study does not claim that conservative attitudes did not play any role in lowering women's labor market outcomes. However, it argues that when the headscarf was banned, it did not leave any room for women coming from conservative families to pursue avenues of self-development. Their access to higher education institutions were cut off. Nor could they find well-paying jobs. One argument for the enforcement of the headscarf ban was that the ban could emancipate these women from the oppression of their male family member. But, that supposition is far too simplistic. When the women wearing a headscarf is faced with a choice of 'working at a job without a headscarf' or 'staying home', most just could not work because this was no choice at all. Indeed, for women who wear the headscarf willingly, the choice of removing the 
headscarf could be out of question as that would produce cognitive dissonance. For those who wear the headscarf as per their family's request may found it hard to remove it even if they wanted to do so, as Ugur (2017, p. 21) demonstrates that men with headscarved wives are the most likely to disapprove its removal for the sake of continuing of the woman's education. Indeed, even legally, married women needed to get their husbands' approval, as until 2003 the Turkish legal code made it mandatory for married women to get their husbands' permission to join the labor market. However, if there were a third option of working with the headscarf, it could give women a lot more bargaining power over participating in the labor market in a socially accepted way. Actually, Mahmud (2005; p.6) explains that upholding social norms, such as modesty, humility, are necessary conditions for women's enhanced public role in socially conservative societies. As wearing a headscarf is mostly associated with modesty (Ugur, 2017, p. 22), naturally wearing it can bring autonomy to women in a socially accepted way, in line with suggestions of Mule \& Barthel (1992).

\section{Conclusion}

The interplay between secularism and the use of headscarves was a very controversial issue for Turkey at the end of 1997. Even today, many European countries are struggling to find the right approach to integrate headscarves in a secular setting, without restricting women's religious freedom.

In Turkey, the majority of the public was against the headscarf ban. However, the ban was implemented very strictly between 1998 and 2008. As many studies show, more than $60 \%$ of women in Turkey wear headscarves and it is expected that ban led to lower labor market prospects for women wearing them. Therefore, in this study, the repercussions of the ban on women's labor market outcomes was examined using two rounds of NDHS conducted in 2003 and 2008, and another two surveys conducted by the Konda Research Company in 2007 and 2011.

Descriptive statistics from both datasets show that women wearing headscarves generally come from disadvantaged 
backgrounds (have parents with less education, more likely to speak Kurdish as their mother tongue, being born and living in Black Sea region, Central and South-East parts of Turkey). Moreover, there is a wide gap in their social values, as women without the headscarf are more likely to value material affluence and be more career-oriented. Even after accounting for the effect of religiosity, other religious behaviors, such as praying 5 times a day, reading the Quran etc, and social values, urban women wearing the headscarf are 3.6\% to $8.5 \%$ less likely to be employed. In conclusion, the headscarf ban, which was in effect when our surveys were conducted (between 2003 to 2011), was not conducive to the employment of women who wore a headscarf.

\section{References}

AK-DER. (2010). Toplumsal Cinsiyet, Eşitlik \& Başörtüsü Yasakları. Retrieved from http://www.akder.org/grafik/manager/Dokumanlar/ istatistik\%20raporu\%202010_t\%C3\%BCrk\%C3\%A7e.pdf

Aksoy, M. (2005). Başörtüsü-türban: batılılaşma-modernleşme, laiklik ve örtünme. İstanbul: Kitap Yayınevi.

Assad, R. (2005). Informalization and Defeminization: Explaining the Unusual Pattern in Egypt. In N. Kudva \& L. Benerı'a (Eds.), Rethinking Informalization: Poverty, Precarious Jobs and Social Protection (pp. 86-102): Cornell University Open Access Repository.

Atasoy, B. S. (2016). Female Labour Force Participation in Turkey: The Role of Traditionalism. The European Journal of Development Research, 29, 675-707.

Başlevent, C., \& Onaran, Ö. (2004). The Effect of Export-Oriented Growth on Female Labor Market Outcomes in Turkey. World Development, 32(8), 1375-1393.

Benli, F. (2011). 1964-2011 Türkiye'de ve Dünya'da Başörtüsü Yasağı Kronolojisi. Retrieved from İstanbul: BK (Biz Kimiz) 2011: Individual Level Data-İstanbul: Konda Research Company.

Cagatay, N., \& Ozler, S. (1995). Feminization of the labor force: The effects of long-term development and structural adjustment. World Development, 23(11), 1883-1894.

Carkoglu, A., \& Toprak, B. (2006). Religion, Society and Politics in Changing Turkey (Değişen Türkiye'de Din, Toplum Siyaset). İstanbul: TESEV.

Carvalho, J. (2013). Veiling. Quarterly Journal of Economics, 128(1), 337-370. 
Chick, K. (2010). Veil ban: Why Syria joins Europe in barring the niqab. Retrieved from http://www.csmonitor.com/World/Middle-East/2010/0720/ Veil-ban-Why-Syria-joins-Europe-in-barring-the-niqab

Cindoglu, D. (2010). Headscarved Women In Professional Jobs: Revisiting Discrimination. Istanbul: TESEV.

Clark, R., Ramsbey, T. W., \& Adler, E. S. (1991). Culture, gender, and labour force participation: A crossnational study. Gender and Society, 5(1), $47-66$.

Dayioglu, M. (2000). Labor market participation of women in Turkey. In F. Acar \& A. Gunes-Ayata (Eds.), Gender and Identity Construction: Women of Central Asia, the Caucasus and Turkey. Leiden: Brill.

Dayığlu, M., \& Kırdar, M. G. (2010). Determinants of and Trends in Labor Force Participation of Women in Turkey. Retrieved from Ankara:

Dedeoğlu, S. (2010). Visible Hands - Invisible Women: Garment Production in Turkey. Feminist Economics, 16(4), 1-32.

Dunbar, H. (2009). Tunisian Women's Current Liberties and Future Plans for Advancement. Illinois.

Fernandez, R., Fogli, A., \& Olivetti, C. (2004). Mothers and sons: Preference formation and female labour force dynamics. Quarterly Journal of Economics, 119, 1249-1299.

Forum, W. E. (2007). The Global Gender Gap. Retrieved from Geneva: http:// reports.weforum.org/global-gender-gap-report-2007/.

Forum, W. E. (2016). The Global Gender Gap Retrieved from Geneva: http:// reports.weforum.org/global-gender-gap-report-2016/

Göksel, İ. (2013). Female labor force participation in Turkey: The role of conservatism. Women's Studies International Forum, 45-54.

GYDLTA (Gündelik Yaşamda Din Laiklik ve Türban Araştırması) 2007: Individual Level Data-İstanbul: Konda Research Company.

Hoodfar, V. (1991). Return to the veil Working Women: International Perspectives on Labour and Gender Ideology (pp. 104-124). New York: Routledge.

Human Rights Watch. (2009). Discrimination in the Name of Neutrality: Headscarf Bans for Teachers and Civil Servants in Germany. Retrieved from http://www.hrw.org/sites/default/files/reports/germany0209_web.pdf

Hürriyet, 2003, http://www.hurriyet.com.tr/gundem/annem-de-basortulu -ama-turban-siyasi-simge-38511898

İkkaracan, I. (2012). Why so few women in the labor market in Turkey? Feminist Economics, 18(1), 1-37.

Jenkins, G. (2008). Political Islam in Turkey: Running West, Heading East? New York: Palgrave Macmillan. 
Karaoglan, D., \& Okten, C. (2012). Labor force participation of married women in Turkey: Is there an added or a discouraged worker effect? IZA Discussion Paper.

Kottis, A. P. (1990). Shifts Over Time and Regional Variation in Women's Labor Force Participation Rates in a Developing Economy. Journal of Development Economics, 33, 117-132.

Kuru, A. (2009) Secularism and State Policies toward Religion The United States, France, and Turkey. Cambridge: Cambridge University Press.

Mahmud, S. (2005) Politics of Piety. New Jersey: Princeton University Press.

Mardell, M. (2006). Dutch MPs to decide on burqa ban. Retrieved from BBC News: http://news.bbc.co.uk/2/hi/europe/4616664.stm

Mule, P., \& Barthel, D. (1992). The Return to the Veil: Individual Autonomy vs. Social Esteem. Sociological Forum, 323-332.

National Security Council. (1997, February 28). Decision No: 406 Appendix A.

NDHS (National Demograhic Health Survey) 2003-2008: Individual Level Data-Ankara: Hacettepe Institute of Population Studies.

Read, J. G., \& Bartkowski, J. (2000). To veil or not to veil? A case study of identity negotiation among Muslim Women in Austin, Texas. Gender and Society, 395-417.

Saharso, S. (2007). Headscarves: A Comparison of Public Thought and Public Policy in Germany and the Netherlands. Critical Review of International Social and Political Philosophy, 513-530.

TA (Türban Araştırması) 2003-2007: Individual Level Data: İstanbul: Adil Gür Research Company.

Tansel, A. (2001). Economic Development And Female Labor Force Participation In Turkey: Time-Series Evidence And Cross-Province Estimates ERC Working Papers.

The Official NewsPaper. (1982). Sayı: 25/10/1982 - 17849. 2.

The Official Newspaper. (2008). ANAYASA MAHKEMESI KARARI.

Ugur, Z. B. (2017). Unveiling the Veil: The impact of Headscarf Ban on Educational Attainment of Women in Turkey. Working Paper.

Union of Turkish Bar Associations, Meslek Kuralları 20. Madde, (1971).

Vakulenko, A. (2007). Islamic Headscarves and the European Convention on Human Rights. Social Legal Studies, 183-199. 


\section{Appendix}

Figure A-1. Labor Force Participation Rate by Gender

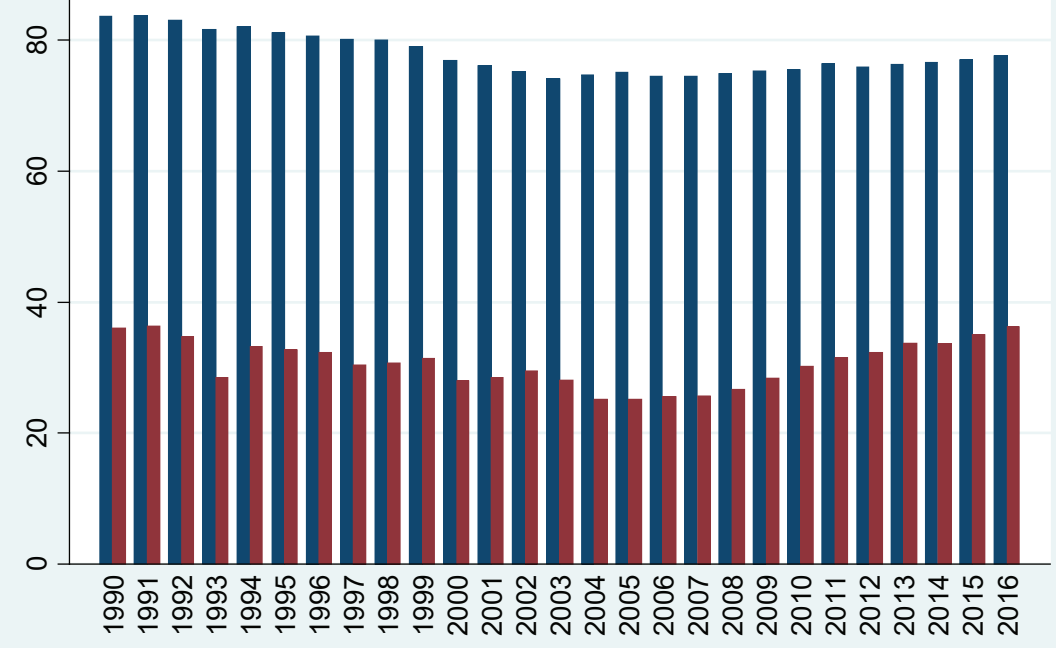

Male

Female

Source: OECD, Labor Statistics 


\begin{tabular}{|c|c|c|}
\hline & NDHS-2003 & NDHS-2008 \\
\hline \multirow[t]{2}{*}{ Headscarf } & -0.007 & -0.008 \\
\hline & $(-0.85)$ & $(-0.89)$ \\
\hline \multirow[t]{2}{*}{ Educ } & $0.052^{* * *}$ & $0.044^{* * *}$ \\
\hline & $(0.01)$ & $(0.01)$ \\
\hline \multirow[t]{2}{*}{ Age } & $0.004^{* * *}$ & $0.006^{* * *}$ \\
\hline & $(0.00)$ & $(0.00)$ \\
\hline \multirow[t]{2}{*}{ Mother's education level } & 0.005 & $0.029^{* * *}$ \\
\hline & $(0.01)$ & $(0.01)$ \\
\hline \multirow[t]{2}{*}{ Father's education level } & $0.013^{* *}$ & -0.004 \\
\hline & $(0.01)$ & $(0.01)$ \\
\hline Mother tongue: Turkish & $0.082^{* *}$ & -0.019 \\
\hline (base: other language) & $(0.03)$ & $(0.04)$ \\
\hline \multirow[t]{2}{*}{ Mother tongue: Kurdish } & $0.109 * * *$ & 0.006 \\
\hline & $(0.04)$ & $(0.04)$ \\
\hline West & $0.047^{\star \star *}$ & $0.086^{\star * *}$ \\
\hline (base: Eastern Turkey) & $(0.02)$ & $(0.02)$ \\
\hline \multirow[t]{2}{*}{ South } & 0.002 & 0.023 \\
\hline & $(0.02)$ & $(0.02)$ \\
\hline \multirow[t]{2}{*}{ Central } & -0.009 & -0.012 \\
\hline & $(0.02)$ & $(0.02)$ \\
\hline \multirow[t]{2}{*}{ North } & $0.046^{\star *}$ & $0.209^{* * *}$ \\
\hline & $(0.02)$ & $(0.02)$ \\
\hline \multirow[t]{2}{*}{ Wealth Index } & $-0.024^{\star * *}$ & $-0.021^{* * *}$ \\
\hline & $(0.01)$ & $(0.01)$ \\
\hline \multirow[t]{2}{*}{$\mathrm{N}$ of Children } & -0.002 & $-0.010^{* *}$ \\
\hline & $(0.00)$ & $(0.00)$ \\
\hline \multirow[t]{2}{*}{ Wears make-up } & -0.011 & \\
\hline & $(0.01)$ & \\
\hline \multirow[t]{2}{*}{ Had religious education } & 0.001 & \\
\hline & $(0.01)$ & \\
\hline \multirow[t]{2}{*}{ Prays } & & -0.011 \\
\hline & & $(0.01)$ \\
\hline \multirow[t]{2}{*}{ Fasts } & & $-0.026^{\star *}$ \\
\hline & & $(0.01)$ \\
\hline $\mathrm{N}$ & 5,472 & 5,084 \\
\hline Pseudo R-sqr & 0.066 & 0.089 \\
\hline
\end{tabular}

Table A-1. Probit Estimates of Emploment Status (Marginal Effects) -NDHS

Notes: standard errors are in ()$,{ }^{* * *} \mathrm{p}<0.01,{ }^{* *} \mathrm{p}<0.05,{ }^{*} \mathrm{p}<0.10$ 


\begin{tabular}{|c|c|c|}
\hline & 2007 & 2011 \\
\hline \multirow[t]{2}{*}{ Headscarf } & $-0.061^{* * *}$ & $-0.036^{* *}$ \\
\hline & $(0.02)$ & $(0.02)$ \\
\hline \multirow[t]{2}{*}{ Education } & $0.063^{* * *}$ & $0.057^{* * *}$ \\
\hline & $(0.01)$ & $(0.01)$ \\
\hline \multirow[t]{2}{*}{ Age } & -0.020 & 0.004 \\
\hline & $(0.01)$ & $(0.01)$ \\
\hline \multirow[t]{2}{*}{ Household size } & -0.018 & 0.003 \\
\hline & $(0.02)$ & $(0.01)$ \\
\hline \multirow[t]{2}{*}{ Family income } & $0.030^{* * *}$ & $0.045^{* * *}$ \\
\hline & $(0.01)$ & $(0.01)$ \\
\hline \multirow[t]{2}{*}{ Single/Engaged } & $0.074^{*}$ & $0.070^{\star *}$ \\
\hline & $(0.04)$ & $(0.03)$ \\
\hline \multirow[t]{2}{*}{ Married } & -0.015 & -0.031 \\
\hline & $(0.04)$ & $(0.03)$ \\
\hline \multirow[t]{2}{*}{ Self-reported Religiosity } & $0.044^{\star * *}$ & -0.006 \\
\hline & $(0.02)$ & $(0.01)$ \\
\hline \multirow[t]{2}{*}{ Frequency of 5 daily prayers } & -0.024 & -0.011 \\
\hline & $(0.02)$ & $(0.01)$ \\
\hline \multirow[t]{2}{*}{ Frequency of fasting } & $-0.040^{\star *}$ & 0.009 \\
\hline & $(0.02)$ & $(0.01)$ \\
\hline \multirow[t]{2}{*}{ Frequency of reading Quran } & $-0.038^{* * *}$ & \\
\hline & $(0.01)$ & \\
\hline \multirow[t]{2}{*}{ Frequency of voluntarily praying } & 0.015 & \\
\hline & $(0.02)$ & \\
\hline \multirow[t]{2}{*}{ Women should be able to work } & 0.012 & \\
\hline & $(0.02)$ & \\
\hline \multirow[t]{2}{*}{ Values Material Wealth } & -0.001 & \\
\hline & $(0.04)$ & \\
\hline \multirow[t]{2}{*}{ Values Modern Family Life } & -0.025 & \\
\hline & $(0.02)$ & \\
\hline \multirow[t]{2}{*}{ Values Career } & $0.058^{* * *}$ & \\
\hline & $(0.02)$ & \\
\hline \multirow[t]{2}{*}{ New Technologies Beneficial } & & -0.002 \\
\hline & & $(0.01)$ \\
\hline $\mathrm{N}$ & 1,574 & 2,680 \\
\hline Pseudo R-squared & 0.171 & 0.167 \\
\hline
\end{tabular}

Table A-2. Probit Estimates of Employment Status (Marginal Effects)- Konda

St. errors are in ( ), ${ }^{* * *} \mathrm{p}<0.01,{ }^{* *} \mathrm{p}<0.05,{ }^{*} \mathrm{p}<0.10$,

Notes: Regression results include 12 region of residence dummy variables and 13 region of birth dummy variables. 